\title{
The Experimental Generation of Antibodies to $\alpha$-Melanocyte Stimulating Hormone and Adrenocorticotropic Hormone *
}

\author{
Joseph McGuire, $†$ Raymond McGill, Susan Leeman, and \\ THEODORE GOODFRIEND + \\ (From the Department of Medicine, Section of Dermatology, Yale University, New Haven, \\ Conn.; the Department of Dermatology, Massachusetts General Hospital, Boston, \\ Mass.; and the Graduate Department of Biochemistry, Brandeis University,§ \\ Waltham, Mass.)
}

Sensitivity, reproducibility, and specificity are requirements for a suitable assay for hormones. The quantitation of $\alpha-\mathrm{MSH}^{1}$ is currently based on a technique devised in 1954, which utilized isolated pieces of frog skin (1). In the presence of $\alpha$-MSH, frog skin darkens with a measurable decrease in the reflection of light from the skin. Although this assay possesses great sensitivity (less than $10^{-11} \mathrm{~g}$ of $\alpha$-MSH), it does not have the degree of specificity necessary to discriminate among the several substances that darken frog skin, such as ACTH and $\alpha$ - and $\beta$-MSH. This lack of specificity has prevented application of the in vitro frog skin assay to clinical problems.

Immunochemical techniques have become useful for the measurement of several small polypep-

* Submitted for publication March 25, 1965 ; accepted June 29, 1965.

These studies were supported in part by U. S. Public Health Service grants AM 08073, AM 1003, AM K35509, and HD-01120.

Presented in part at the meeting of the American Federation for Clinical Research, Atlantic City, N. J., May 2, 1965 .

$\dagger$ Address requests for reprints to Dr. Joseph S. McGuire, Dept. of Internal Medicine, Yale University School of Medicine, New Haven, Conn. 06510.

$\ddagger$ Fellow of the Helen Hay Whitney Foundation. Present address, Departments of Medicine and Pharmacology, School of Medicine, University of Wisconsin, Madison, Wis.

§ Publication no. 370.

1 Abbreviations: MSH, melanocyte stimulating hormone; ACTH, adrenocorticotropic hormone; RSA, rabbit serum albumin; anti-ACTH, serum from rabbits that have received injections of rabbit serum albumin conjugated with $\mathrm{ACTH}$; anti-MSH, serum from rabbits that have received injections of rabbit serum albumin conjugated with $\alpha$-MSH; eicosapeptide "ACTH," the synthetic $\mathrm{N}$ - terminal eicosapeptide of ACTH. tide hormones, including insulin (2), glucagon (3), parathormone $(4,5)$, and $\operatorname{ACTH}(6,7)$. These techniques depend on the availability of antibodies to the hormones. Alpha-MSH is a small polypeptide with a molecular weight of 1,665 , and the occurrence of antibodies to this peptide has not been described. We report the generation of antibodies to $\alpha$-MSH and ACTH in rabbits and suggest that the use of antisera may confer immunologic specificity to the bioassay of $\alpha-\mathrm{MSH}$, and may be useful for direct immunochemical measurement of the hormone.

\section{Methods}

Antigenic compounds were synthesized by conjugating rabbit serum albumin (RSA) with either $\alpha$-MSH or ACTH by means of the carbodiimide reagent [1-ethyl3-(3-dimethyl-aminopropyl) carbodiimide], as previously described for bradykinin and other peptides (8). Five $\mathrm{mg}$ of albumin, $5 \mathrm{mg}$ of $\alpha-\mathrm{MSH}$ or ACTH, and $100 \mathrm{mg}$ of the carbodiimide reagent were dissolved, in that order, in $0.3 \mathrm{ml}$ water. After 30 minutes a cloudy, gelatinous precipitate formed. The entire mixture was then subjected to dialysis against water for 48 hours. The precipitated material was used for immunization. Antigens for complement fixation were prepared in the same way, except that a different carbodiimide [1-cyclohexyl-3-(2morpholinyl-(4)-ethyl) carbodiimide metho-p-toluenesulfonate] was used to reduce interference by possible antibodies to the reagents. Three $\mathrm{mg}$ of the albumin-hormone conjugate (RSA-MSH or RSA-ACTH) was emulsified in Freund's adjuvant and injected into the toe pads and leg muscles of New Zealand albino rabbits. After 3 weeks, $2 \mathrm{mg}$ of the compound in adjuvant was injected intraperitoneally, and 2 weeks later serum was collected. Further booster injections were administered intraperitoneally at monthly intervals. Antibodies were detectable after the first boost. Each of the sera used in these studies was obtained after the fifth boost from a single bleeding of one rabbit. Sera were not pooled.

Antibodies were detected by complement fixation, us- 



Fig. 1. Complement fiXation by RabBit SERUM ALBUMIN-ADRENOCORTICOTROPIC HORMONE (RSA-ACTH) AND MELANOCYTE STIMULATING HORMONE (RSA-MSH) AND THE ANTISERA INDUCED BY THESE COMPLEXES. These assays were performed as described in the text. One $\mathrm{ml}$ of diluted antiserum was used for each point. The dilution of anti-ACTH was $1: 100$ and of anti-MSH was $1: 25$.

ing the technique of Wasserman and Levine (9), and specificity was assessed by cross-reactivity of the antisera with other hormone-albumin complexes and by "hapten inhibition" of the complement fixation reaction by free peptides. The dilutions of antisera and the amounts of antigen required for maximal complement fixation were confirmed in three separate experiments, one of which is shown in Figure 1 for each antigen-antibody system. The hapten inhibition studies were performed several times. One complete study is summarized in Table I; the others confirmed the relative amounts of hormones required for inhibition of complement fixation by the two antisera.
Frog skin bioassay for darkening activity. Four skin samples were obtained from each frog and mounted on rings as previously described (1). Each compound was tested on a total of four samples from different regions of four frogs. In this way the darkening activity of four substances could be compared in a latin square. The frogs were decapitated and skinned at 7:30 a.m. The skins were trimmed, mounted on rings, placed in beakers, and washed in five changes of Ringer's solution. Peptide was added at 11:00 a.m. A darkening unit was defined as the degree of darkening produced by $0.04 \mu \mathrm{g}$ of a lyophilized water extract of beef posterior pituitary powder (1). Peptides were assayed before use. In each experiment, $10 \mathrm{U}$ of the above posterior pituitary standard was added to a group of skins. The standard, unlike the purified peptide, was not mixed with buffer at room temperature for 30 minutes before being added to the frog skin. For this reason, occasionally the $10-\mathrm{U}$ standard produced more darkening than $20 \mathrm{U}$ of purified MSH that had been at room temperature for 30 minutes. Reflectance, which decreases as the skin darkens, was measured by a Photovolt 610 reflectance meter. The meter was calibrated as previously described (1), except that sensitivity control was adjusted to 65 for a white enamel disk with a green filter. Antiserum was added to $0.2 \mathrm{ml}$ Ringer's solution in cellulose nitrate tubes containing the desired amount of peptide. After 30 minutes at room temperature, the mixture was quantitatively transferred to beakers containing the frog skin.

Bioassays for ACTH. Hypophysectomized rats ( 80 to $100 \mathrm{~g}$ ), anesthetized with ether, received ACTH or a mixture of ACTH and antiserum that had been preincubated for 30 minutes at room temperature. The injections were made into a tail vein. Fifteen minutes later, the rats were decapitated and plasma was collected. Plasma steroids were measured by the method of Guillemin, Clayton, Lipscomb, and Smith (10).

TABLE I

Inhibition of complement fixation by unconjugated peptides*

\begin{tabular}{|c|c|c|}
\hline Fixation inhibited & Inhibitor & $\begin{array}{l}\text { Amount } \\
\text { for 50\% } \\
\text { inhibition }\end{array}$ \\
\hline $\begin{array}{l}\text { RSA- } \alpha \text {-MSH†: } \\
\text { Anti-MSH (1 ml) }\end{array}$ & $\begin{array}{l}\alpha \text {-MSH } \\
\beta \text {-MSH } \\
\text { ACTH } \\
\text { Eicosapeptide } \\
\text { "ACTH" }\end{array}$ & $\begin{array}{r}\mu g \\
10 \\
>500 \\
>500 \\
>500\end{array}$ \\
\hline $\begin{array}{l}\text { RSA-ACTH : } \\
\text { Anti-ACTH }(1 \mathrm{ml})\end{array}$ & $\begin{array}{l}\alpha \text {-MSH } \\
\beta \text {-MSH } \\
\text { ACTH } \\
\text { Eicosapeptide } \\
\text { "ACTH" }\end{array}$ & $\begin{array}{l}2.3 \\
7.5 \\
0.85 \\
1.15\end{array}$ \\
\hline
\end{tabular}

* The fixation points were the points of maximal fixation shown in Figure 1. Free hormone was added with the antigenic complex; otherwise the tests were performed according to the text and Wasserman and Levine (9). Points of $50 \%$ inhibition were derived from plots of log concentration of hormone against $\log y / 1 \times y$ where $y=$ per cent inhibition. Data have been corrected to apply to the reaction of $1 \mathrm{ml}$ of undiluted antiserum.

† RSA = rabbit serum albumin; $\mathbf{M S H}=$ melanocyte stimulating hormone; $\mathrm{ACTH}=$ adrenocorticotropic hormone; "ACTH" = synthetic N-terminal eicosapeptide of ACTH. 

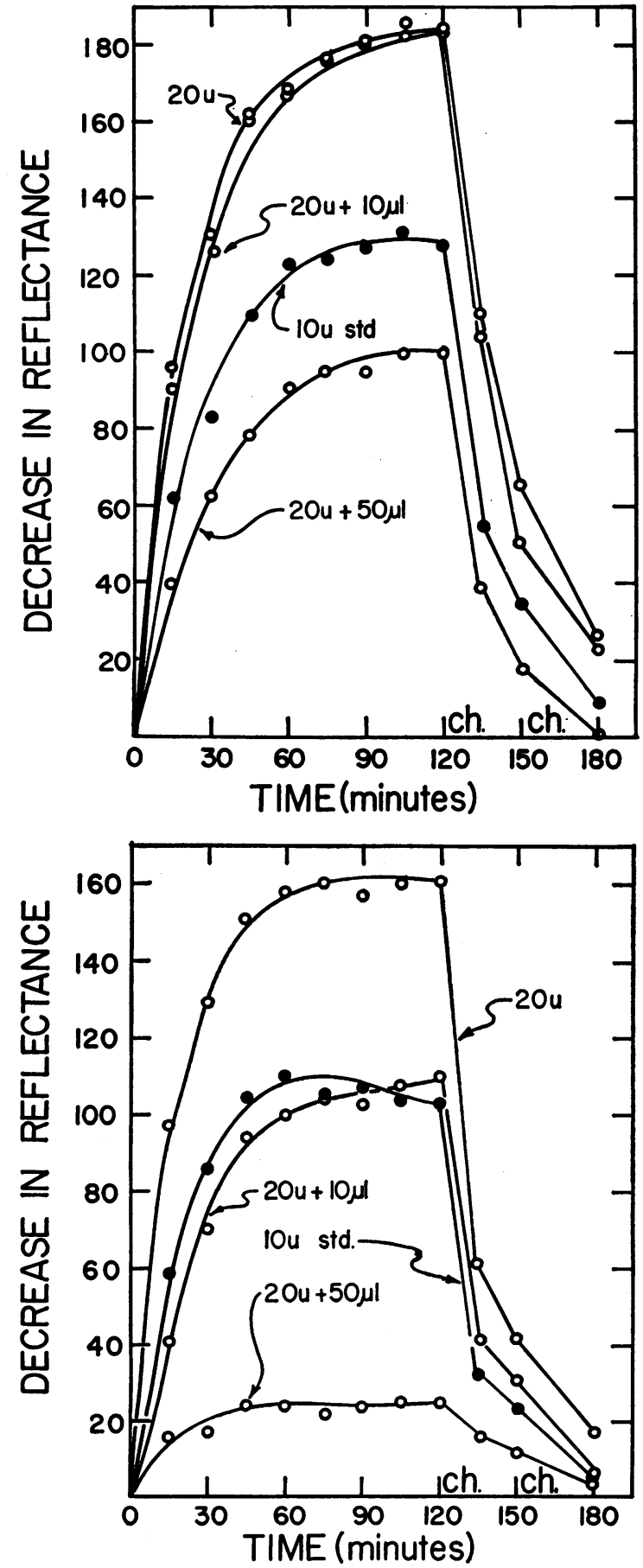

Fig. 2. INHIBItIon BY ANTISERUM OF THE FROG SKIN DARKENING EFFECT of $\alpha$-MSH. Two-tenths $\mathrm{ml}$ Ringer's solution containing $20 \mathrm{U} \alpha$-MSH $\left(2.5 \times 10^{-5} \mu \mathrm{g}\right)$ was mixed where indicated with antiserum in cellulose nitrate tubes at room temperature. Thirty minutes later, the contents of each tube were quantitatively transferred to a beaker containing the skin specimen. The time of transfer is zero time in the Figure. Reflectance readings were
TABLE II

Effects of antibodies to $A C T H$ and $M S H$ on response to ACTH of adrenal tumor cells in tissue culture*

\begin{tabular}{|c|c|c|c|c|c|}
\hline \multirow[b]{2}{*}{ ACTH } & \multirow[b]{2}{*}{ Antiserum } & \multicolumn{2}{|c|}{$\begin{array}{l}\text { OD } 250 \\
\times 1,000\end{array}$} & \multicolumn{2}{|c|}{$\begin{array}{l}\text { Inhibition by } \\
\text { antiserum }\end{array}$} \\
\hline & & Exp. 1 & Exp. 2 & Exp. 1 & Exp. 2 \\
\hline$\mu g$ & $\mu l$ & & & & \\
\hline 0.05 & $\begin{array}{l}0 \\
0\end{array}$ & 136 & & & \\
\hline 0.10 & Anti-ACTH (100) & $\begin{array}{r}180 \\
70\end{array}$ & 153 & 62 & 62 \\
\hline 0.10 & Anti-ACTH (33) & 152 & & 18 & \\
\hline $\begin{array}{l}0.10 \\
0.10\end{array}$ & Anti-ACTH (11) & 191 & 480 & ${ }_{4+}^{0}$ & \\
\hline 0.10 & Anti-MSH (100) & 179 & & $4 \dagger$ & $\mathbf{0}$ \\
\hline
\end{tabular}

* Mouse adrenal tumor cells were dispersed with trypsin and incubated as a monolayer in tissue culture plates with nutrient medium. Two days later, the medium was replaced by a balanced salt solution containing bovine serum albumin, $20 \mathrm{mg}$ per $\mathrm{ml}$, and bovine ACTH with or without antiserum, as indicated. The antiserum-ACTH mixtures were pre-incubated for 1 hour at $0^{\circ} \mathrm{C}$ before addition. After 2 hours (experiment 1) or 7 hours (experiment 2), the salt solution was removed from the plates and extracted with dichloromethane. absorbancy of the dichloromethane at $240 \mathrm{m \mu}$ was used as a measure of $\Delta^{4}$-3-ketosteroid production. The figures represent the total optical density units per culture plate. Each represents the mean of two closely matching plates. linear plot of ACTH against response. In this was read from a represents $10 \mu \mathrm{g}$ of steroid.

$\dagger$ The apparent effects of anti-MSH were not significant.

Mouse adrenal tumor cells were incubated in culture as described by Buonassisi, Sato, and Cohen (11). ACTH and serum were added to the culture dishes on the day after the tumor was plated. Steroid secretion was measured by extracting the medium 2 hours later with dichloromethane. The solvent was evaporated, the residue redissolved in ethanol, and the absorbancy measured at $240 \mathrm{~m} \mu$. Results of two experiments are recorded in Table II.

Materials. Highly purified $\alpha-\mathrm{MSH}$ (porcine) free of ACTH was obtained by elution from a carboxymethylcellulose column. ACTH (porcine) free of $\alpha-\mathrm{MSH}^{2}$ and eicosapeptide "ACTH" 3 were gifts. The rabbit albumin, 4 the carbodiimides, ${ }^{5}$ and the hypophysectomized rats ${ }^{6}$ were purchased.

2 Arthur Cohen, Abbott Laboratories, North Chicago, III.

3 Professor Klaus Hofmann, University of Pittsburgh, Pittsburgh, $\mathrm{Pa}$.

4 Pentex, Kankakee, III.

5 Ott Chemical Co., Muskegon, Mich., and Aldrich Chemical Co., Milwaukee, Wis.

${ }^{6}$ Hormone Assay Laboratories, Chicago, Ill.

made at 15-minute intervals. Each curve represents the sum of reflectance changes for four separate skin specimens. The activity of $\alpha$-MSH used in this experiment was $8 \times 10^{11} \mathrm{U}$ per $\mathrm{g} ; 20 \mathrm{U}$ represented $2.5 \times 10^{-5} \mu \mathrm{g}$. The 10-U standard (STD) was the crude extract of pituitary described in the Methods. The standard did not sit at room temperature for 30 minutes but was added directly to the beakers. In the upper portion of the Figure, 10 and $50 \mu \mathrm{l}$ of anti-MSH were used where indicated. In the lower, $10 \mu 1$ and $50 \mu 1$ of anti-ACTH were used. The Ringer's solution was changed at 120 and $150 \mathrm{~min}$ utes, as indicated by "ch." 

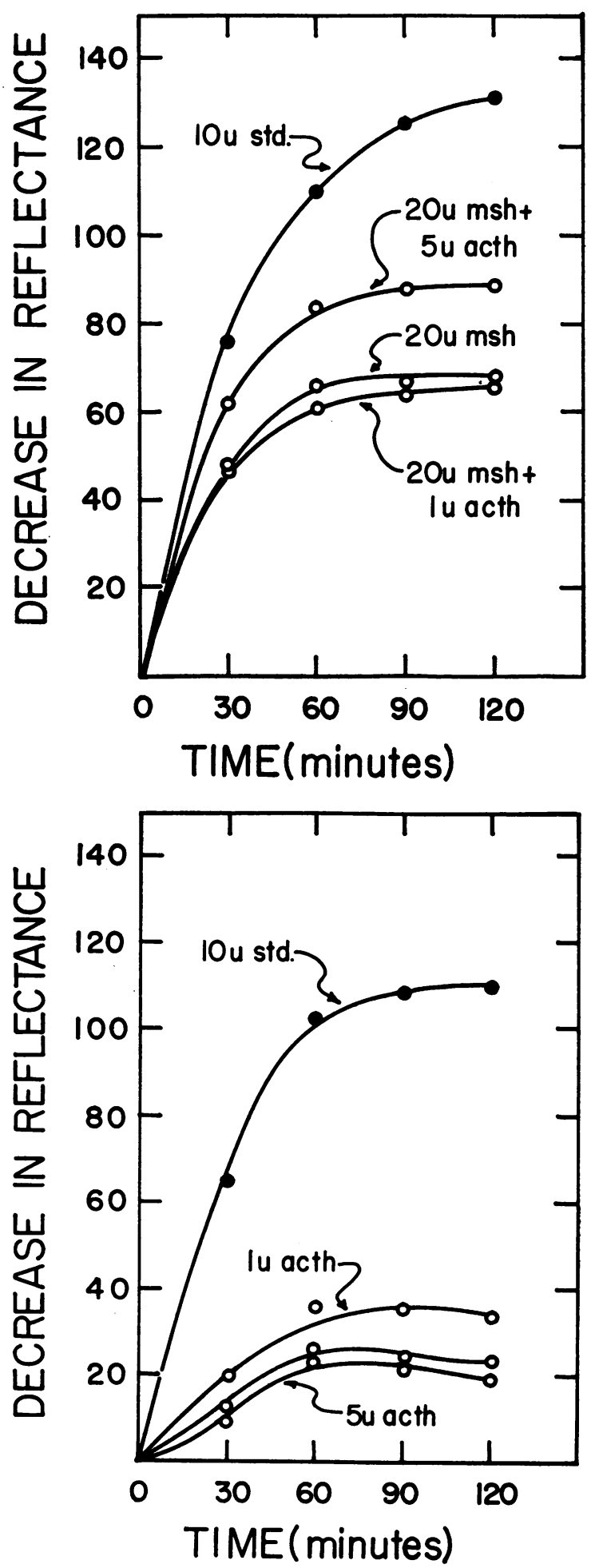

FIG. 3. INHIBITION OF FROG SKIN DARKENING BY ANTIMSH. Peptides and antiserum were mixed as in Figure 2; zero time is the time of the addition of peptide to the frog skins. The darkening activity of the ACTH was

\section{Results}

The antisera induced by RSA-MSH and RSAACTH fixed complement with homologous complexes, as illustrated in Figure 1. The titers for complete fixation with the homologous antigenic complexes under standard conditions were 1:25 for anti-MSH and 1:100 for anti-ACTH. AntiMSH did not cross-react with RSA-ACTH, but anti-ACTH did fix complement in the presence of RSA-MSH at a titer of $1: 50$. Similar specificity characteristics were evident in hapten inhibition assays (Table I). The reaction of RSA-MSH with anti-MSH was inhibited by $\alpha$-MSH but not by $\beta$-MSH, ACTH, or the eicosapeptide "ACTH." In contrast, the reaction of RSA-ACTH with anti-ACTH was inhibited by ACTH, eicosapeptide "ACTH," and $\alpha$ - and $\beta$-MSH.

Anti-ACTH showed a greater affinity for $\mathrm{MSH}$ than did anti-MSH itself. The reaction of $1 \mathrm{ml}$ of anti-ACTH with RSA-ACTH was inhibited $50 \%$ by $2.3 \mu \mathrm{g} \alpha$-MSH, but the reaction of $1 \mathrm{ml}$ anti-MSH with RSA- $\alpha$-MSH required $10 \mu \mathrm{g}$ of $\alpha$-MSH for $50 \%$ inhibition. The smaller amount of hapten required for inhibition of complement fixation reflects the greater ability of anti-ACTH to bind free $\alpha-\mathrm{MSH}$.

Anti-MSH and anti-ACTH decreased the darkening effect of $\alpha-\mathrm{MSH}$ as indicated in Figure 2. In the experiment shown in the upper Figure, $20 \mathrm{U}$ of $\alpha$-MSH $\left(2.5 \times 10^{-5} \mu \mathrm{g}\right)$ was mixed with either $10 \mu \mathrm{l}$ or $50 \mu \mathrm{l}$ of anti-MSH. Ten $\mu$ l of anti-MSH produced no inhibition of $\mathrm{MSH}$ darkening, whereas $50 \mu 1$ produced approximately $50 \%$ inhibition. Anti-MSH inhibited the darkening effect of $\alpha$-MSH but not the darkening effect of $\beta$-MSH or ACTH. This is in agreement with the immunologic specificity tabulated in Table I. The Figure represents single experiments carried out on 2 dif-

$7 \times 10^{7} \mathrm{U}$ per $\mathrm{g}$; the activity of $\alpha$-MSH was $8 \times 10^{11} \mathrm{U}$ per $g$. The units noted on the Figure refer to darkening activity, not adrenocorticotropic activity. In the upper section of the Figure, the curves with open circles represent the darkening activity of combinations of $\alpha-\mathrm{MSH}$ and ACTH. In the lower section, with the same combinations of peptides, $20 \mu \mathrm{l}$ of anti-MSH has been mixed for 30 minutes. The curves with open circles represent reactions containing $20 \mathrm{U} \alpha-\mathrm{MSH}\left(2.5 \times 10^{-5} \mu \mathrm{g}\right)$, and $0 \mathrm{U}, 1 \mathrm{U}$, or $5 \mathrm{U}$ of ACTH, as indicated. The curves with closed circles in the upper and lower sections represent a $10-U$ standard of crude pituitary extract that has not been mixed with antiserum. 

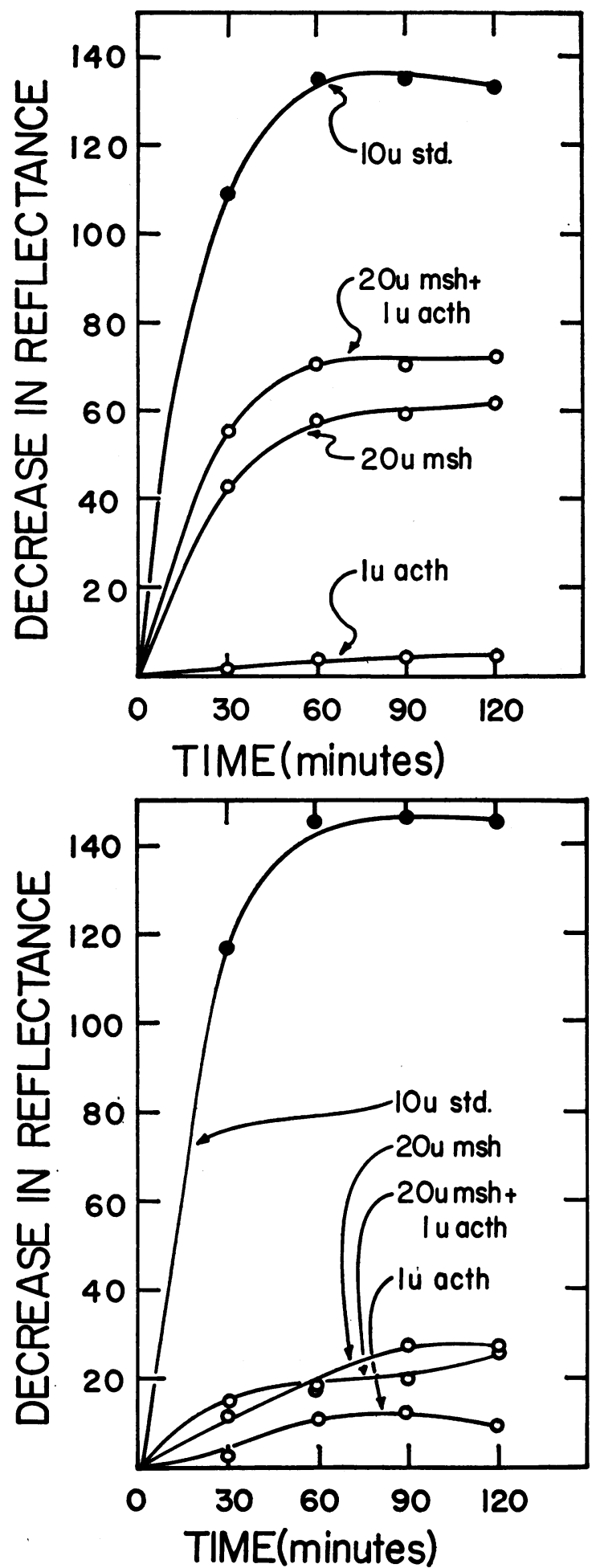

Fig. 4. INHIBITION OF FROG SKIN DARKENING BY ANTIACTH. In the upper part of the Figure no antiserum is used. The 10-U standard effects a greater darkening response than $20 \mathrm{U}$ of $\alpha$-MSH because the standard has not been incubated for 30 minutes at room temperature.
TABLE III

Inhibition by anti-ACTH of plasma steroid response to $A C T H$ in the rat

\begin{tabular}{cc}
\hline \multicolumn{1}{c}{ Material injected } & $\begin{array}{c}\text { Plasma steroids } \\
\text { after 15 minutes }\end{array}$ \\
\hline & $\mu \mathrm{g} / 100 \mathrm{ml} \pm S E$ \\
& $7.4 \pm 0.6$ \\
Saline (7)* & $34.3 \pm 3.1$ \\
$\begin{array}{c}\text { ACTH, 0.05 } \mu \mathrm{g}, \text { plus } \\
\text { normal serum 0.02 } \mathrm{ml} \mathrm{(5)}\end{array}$ & $7.3 \pm 1.2$ \\
$\begin{array}{c}\text { ACTH, 0.05 } \mu \mathrm{g}, \text { plus } \\
\text { anti-ACTH } 0.02 \mathrm{ml}(6)\end{array}$ &
\end{tabular}

* Number in parentheses indicates the number of animals injected.

ferent days. Each experiment has been performed more than 6 times with no substantial variation.

Anti-ACTH was a more potent inhibitor of $\alpha$-MSH darkening than was anti-MSH (Figure $2)$. Ten $\mu 1$ of the anti-ACTH produced $40 \%$ inhibition and $50 \mu \mathrm{l}$ produced $90 \%$ inhibition of the darkening ability of $20 \mathrm{U}$ of $\alpha$-MSH $\left(2.5 \times 10^{-5}\right.$ $\mu \mathrm{g})$. When the Ringer's solution in the beaker containing the frog's skin was replaced at 120 and 150 minutes, there was prompt lightening of the skins. The greater ability of anti-ACTH to inhibit $\alpha-\mathrm{MSH}$, compared to that of anti-MSH, is consistent with the data in Table $I$, which indicate that anti-ACTH has a higher affinity for $\alpha-\mathrm{MSH}$ than does anti-MSH.

In several experiments, $50 \mu \mathrm{l}$ of either anti-MSH or anti-ACTH failed to inhibit the darkening activity of $0.3 \mu \mathrm{g}$ of ACTH. Similarly, $50 \mu \mathrm{l}$ of either antiserum did not inhibit $1 \times 10^{-4} \mu \mathrm{g}$ of $\beta$-MSH.

Serum from a rabbit immunized with RSAinsulin conjugate was used as a "control" in many of the preceding experiments. Twenty or $50 \mu \mathrm{l}$ of insulin antiserum did not inhibit the darkening effect of $20 \mathrm{U}\left(2.5 \times 10^{-5} \mu \mathrm{g}\right) \alpha$-MSH.

Although ACTH darkens frog skin, its darkening potency is approximately $10^{4}$ less on a weight basis than that of $\alpha$-MSH. If the antibody to MSH could not distinguish between $\alpha$-MSH and $\mathrm{ACTH}$, then an amount of ACTH insufficient to darken frog skin might combine with the antibody to $\mathrm{MSH}$ and interfere with the reaction between $\mathrm{MSH}$ and its antibody. The data in Figure 3 indicate that relatively enormous amounts of $\mathrm{ACTH}$ do not interfere with the inhibition of $\alpha$-MSH

The lower part of the Figure duplicates the upper, except that antiserum is added to the three experiments represented by open circles. 
TABLE IV

Summary of antibody effects

\begin{tabular}{|c|c|c|}
\hline Assay & Anti-MSH & Anti-ACTH \\
\hline $\begin{array}{l}\text { Darkening of frog skin } \\
\text { produced by: } \\
\alpha \text {-MSH } \\
\text { ACTH } \\
\beta-\text { MSH }\end{array}$ & $\begin{array}{l}\text { Inhibition } \\
\text { No inhibition } \\
\text { No inhibition }\end{array}$ & $\begin{array}{l}\text { Inhibition } \\
\text { No inhibition } \\
\text { No inhibition }\end{array}$ \\
\hline $\begin{array}{l}\text { Response of mouse adrenal } \\
\text { tumor culture to ACTH }\end{array}$ & No inhibition & Inhibition \\
\hline $\begin{array}{l}\text { Complement fixation with: } \\
\text { RSA-ACTH } \\
\text { RSA- } \alpha \text {-MSH }\end{array}$ & $\begin{array}{l}\text { No } \\
\text { Yes }\end{array}$ & $\begin{array}{l}\text { Yes } \\
\text { Yes }\end{array}$ \\
\hline $\begin{array}{l}\text { Inhibition of homologous } \\
\text { antibody-antigen by: } \\
\text { ACTH } \\
\alpha \text {-MSH } \\
\beta \text {-MSH }\end{array}$ & $\begin{array}{l}\text { No } \\
\text { Yes } \\
\text { No }\end{array}$ & $\begin{array}{l}\text { Yes } \\
\text { Yes } \\
\text { Yes }\end{array}$ \\
\hline
\end{tabular}

darkening by anti-MSH. This observation reflects both the low avidity of anti-MSH for ACTH noted in Table I and the degree of antibody excess needed for neutralization of biological activity of $\alpha$-MSH.

Furthermore, the darkening effect of $\alpha-\mathrm{MSH}$ is inhibited by anti-ACTH even in the presence of ACTH (Figure 4), a finding that could not be predicted from the data in Table I.

In Table III the inhibition by anti-ACTH of the response of hypophysectomized rats to intravenously administered ACTH is demonstrated. Twenty $\mu \mathrm{l}$ of anti-ACTH neutralized $0.05 \mu \mathrm{g}$ of ACTH. Similar results were obtained when adrenal ascorbic acid depletion was measured instead of steroid secretion. A similar equivalence of anti-ACTH and ACTH was observed when the antiserum was used to neutralize the effect of ACTH on steroid secretion by cultured cells from mouse adrenal tumor (Table II). In this experiment $100 \mu \mathrm{l}$ of anti-ACTH inhibited by $75 \%$ the response to $0.1 \mu \mathrm{g}$ of porcine ACTH. Anti-MSH did not inhibit ACTH in this assay.

The several effects of anti-MSH and antiACTH are summarized in Table IV.

\section{Discussion}

Lack of specificity of the in vitro frog skin bioassay for $\alpha$-MSH has prevented its general application to clinical problems. The experiments reported here permit the use of antiserum to confer immunologic specificity to the highly sensitive bioassays for $\alpha$-MSH. Frog skin darkening activity due to $\alpha-\mathrm{MSH}$ in human plasma, for example, could be differentiated from that produced by ACTH or $\beta$-MSH by inhibition by highly specific anti-MSH.
This study compared the reactivity of immunologic and biologic systems with $\alpha$-MSH and ACTH. The ability of both antisera to neutralize the biological activity of $\alpha$-MSH correlated well with their binding of $\alpha-\mathrm{MSH}$ as measured by hapten inhibition. This may indicate that these antibodies and the biological receptor react with the same part of the peptide.

The nonspecificity of anti-ACTH is probably related to the inclusion within ACTH of an amino acid sequence common to $\alpha-\mathrm{MSH}$. If one of the sites in RSA-ACTH that induced antibodies in rabbits includes part of this sequence, those antibodies would also react with the similar sequence in $\alpha-\mathrm{MSH}$. On the other hand, the specificity of anti-MSH may be related to the terminal $\mathrm{N}$-acetyl serine present in $\alpha$-MSH but not in $\beta$-MSH or ACTH. Inclusion of this amino acid in the immunogenic site of $\alpha$-MSH might result in antibodies specific for $\alpha$-MSH relative to ACTH and $\beta$-MSH.

The conjugation of small polypeptides to albumin by reaction with carbodiimides provides a convenient method of synthesis of immunogenic complexes, which induce antibodies specific for the polypeptide moiety. In the case of $\alpha-\mathrm{MSH}$, specific antibodies were rapidly induced by the hormone-RSA conjugate. Unconjugated ACTH, on the other hand, can induce antibodies when injected into rabbits or guinea pigs $(6,7,12,13)$. Antibodies formed in response to unconjugated ACTH are more specific than those produced in the current study. In fact, Imura, Sparks, Grodsky, and Forsham (13) concluded that their antibodies to ACTH reacted with the part of the ACTH molecule that does not contain the $\alpha$-MSH sequence. There probably are two or more immunogenic sites in the ACTH molecule. Differences in results may reflect individuality of the antibody-producing animals, as shown by Arquilla and Finn in guinea pigs producing antibodies to insulin (14). Alternatively, the differences may result from the use of conjugates. Conjugation to albumin may preferentially expose the sites of $\mathrm{ACTH}$ resembling $\mathrm{MSH}$ to the antibody producing mechanisms.

Anti-ACTH inhibits the adrenocorticotropic function of ACTH but not its skin darkening effect. This observation could be explained if the affinity between the melanocyte and ACTH were greater than the affinity between the peptide and 
the antibody. Such a proposal would, however, also require the adrenal cortex to have a relatively lower affinity for ACTH than that of the antibody.

Complement fixation in the presence of RSA$\mathrm{ACTH}$ and anti-ACTH was inhibited by both $\beta$-MSH and ACTH, which indicates that the antibody binds these molecules. Darkening effects of these hormones, however, were not inhibited by the antiserum, which may indicate that the hormone-antibody complex is active at the melanocyte target or that the melanocyte target has very high binding affinity for the hormone compared to the binding by antibody. A large excess of antibody was required for the neutralization of the biological effect compared to the proportions indicated by the immunological data. This supports the idea that melanocytes bind the hormones strongly, compared to their binding by antisera. In in vivo experiments, the antisera were found to prolong the effects of $\alpha$-MSH in frogs, with variable evidence of neutralization (15).

The binding of free hormone indicated by the hapten inhibition data permit use of these antisera for immunoassay of $\alpha$-MSH. The differential abilities of the antisera to neutralize effects of the hormones on frog skin permit their use to add specificity to this sensitive bioassay.

\section{Summary}

Adrenocorticotropic hormone (ACTH) and melanocyte stimulating hormone $(\alpha-\mathrm{MSH})$ were conjugated to rabbit serum albumin with carbodiimide reagents, and the induction of antibodies to these complexes in the rabbit is reported.

Complement fixing antibodies to $\alpha$-MSH were found to be very specific, and they did not crossreact with $\beta-\mathrm{MSH}$ or ACTH. They neutralized the skin darkening effect of $\alpha$-MSH on frog skin in vitro. Antiserum to $\mathrm{ACTH}$ was less specific, and it reacted with ACTH, the synthetic N-terminal eicosapeptide of ACTH (eicosapeptide "ACTH"), and both $\alpha$ - and $\beta$-MSH. AntiACTH neutralized the biological effects of ACTH on rat adrenal gland and adrenal tumor cells and the effect of $\alpha-\mathrm{MSH}$ on frog skin. Neither antiserum in the small amounts used neutralized the darkening effect of $\beta$-MSH or ACTH.

\section{Acknowledgments}

We acknowledge the suggestion by Dr. Arthur Eisen that led to the initial experiments with MSH. We also wish to acknowledge the guidance and advice of Drs. Lawrence Levine, Gordon Sato, and Gerald Fasman. We appreciate the assistance of Dr. Leon Edelstein, Joan Faber, Eleanor Wasserman, Ellen Shear, and Stanko Kulovich.

\section{References}

1. Shizume, K., A. B. Lerner, and T. B. Fitzpatrick. In vitro bioassay for the melanocyte stimulating hormone. Endocrinology 1954, 54, 553.

2. Berson, S. A., and R. S. Yalow in The Hormones, G. Pincus, K. Thimann, and E. Astwood, Eds. New York, Academic Press, 1964, vol. 4, p. 557.

3. Unger, R. H., A. M. Eisentraut, M. S. McCall, and L. L. Madison. Glucagon antibodies and an immunoassay for glucagon. J. clin. Invest. 1961, 40, 1280.

4. Tashjian, A. H., Jr., L. Levine, and P. L. Munson. Production of an antibody to bovine parathyroid hormone. Biochem. biophys. Res. Commun. 1962, 8, 259.

5. Berson, S. A., R. S. Yalow, G. D. Aurbach, and J. T. Potts, Jr. Immunoassay of bovine and human parathyroid hormone. Proc. nat. Acad. Sci. (Wash.) 1963, 49, 613.

6. Felber, J. P. ACTH antibodies and their use for a radioimmunoassay for ACTH. Experientia (Basel) 1963, 19, 227.

7. Yalow, R. S., S. M. Glick, J. Roth, and S. A. Berson. Radioimmunoassay of human plasma ACTH. J. clin. Endocr. 1964, 24, 1219.

8. Goodfriend, T. L., L. Levine, and G. D. Fasman. Antibodies to bradykinin and angiotensin: a use of carbodiimides in immunology. Science 1964, 144, 1344.

9. Wasserman, E., and L. Levine. Quantitative microcomplement fixation and its use in the study of antigenic structure by specific antigen-antibody inhibition. J. Immunol. 1961, 87, 290.

10. Guillemin, R., G. W. Clayton, H. S. Lipscomb, and J. D. Smith. Fluorometric measurement of rat plasma and adrenal corticosterone concentration. J. Lab. clin. Med. 1959, 53, 830.

11. Buonassisi, V., G. Sato, and A. I. Cohen. Hormoneproducing cultures of adrenal and pituitary tumor origin. Proc. nat. Acad. Sci. (Wash.) 1962, 48, 1184.

12. McGarry, E. E., A. Ballantyne, and J. C. Beck, Studies with antisera to corticotropin (ACTH) in Ciba Foundation Colloquium on Endocrinology. 1962, vol. 14, p. 273.

13. Imura, H., L. L. Sparks, G. M. Grodsky, and P. H. Forsham. Dissociation of immunologic and biologic activity of ACTH. Clin. Res. 1965, 13, 106.

14. Arquilla, E. R., and J. Finn. Genetic differences in antibody production to determinant groups on insulin. Science 1963, 142, 400.

15. Goodfriend, T., M. Webster, and J. McGuire. In preparation. 